\title{
Effect of Non-face-to-face Voice Therapy Using the Self-Voice Health Care Program for Vocal fatigue
}

\author{
Ji Sung Kima , Seong Hee Choi ${ }^{\mathrm{b}}$ \\ ${ }^{a}$ Department of Otorhinolaryngology, Chungbuk National University Hospital, Cheongju, Korea \\ ${ }^{b}$ Department of Audiology \& Speech-Language Pathology, DaeguCatholic University, Gyeongsan, Korea
}

\author{
Correspondence: Seong Hee Choi, PhD \\ Department of Audiology and Speech- \\ Language Pathology, Institute of Biomimetic \\ Sensory Control, and Catholic Hearing Voice \\ Speech Center, Daegu Catholic University, \\ 13-13 Hayang-ro, Hayang-eup, Gyeongsan \\ 38430 , Korea \\ Tel: $+82-53-850-2542$ \\ Fax: +82-53-359-6780 \\ E-mail: shgrace@cu.ac.kr
}

Received: January 4, 2021

Revised: February 9, 2021

Accepted: February 23, 2021

\begin{abstract}
Objectives: Covid-19 has increased the need for non-face-to-face treatment. In particular, professional voice users have a high risk of voice disease due to continuous voice use. The purpose of this study was to investigate the effect of the Self-Voice Health Care Program (SVHCP) which was developed on the basis of Korean speech-language pathologist's vocal behaviors, status and vocal fatigue. Methods: Fifteen speech-language pathologists (2 males and 13 females, the average age was 31.19 years) with voice problems who have more than 25 sessions per week participated via an experimental recruitment SMS and posting from the online speech-language pathologists internet community. Participants watched a 5-minute SVHCP video with instructions and carried out SVHCP daily for one week. The voice measures were carried out before and after SVHCP. Results: K-VHI-10 $(p=.017)$, K-VFI-fatigue $(p=.004)$, K-VFI-physical $(p=.019)$, K-VFI-rest $(p=.003)$, K-VFI-total $(p=.005)$ and total subjective vocal symptoms $(p=.009)$ were significantly lower than before. Additionally, among the subjective vocal symptoms, hypertension when speaking $(p=.007)$, roughness when speaking $(p=.007)$, pain when speaking $(p=.034)$, difficulty with high pitch when singing $(p=.017)$, feelings of voice fatigue $(p=.017)$ were significantly lower than before. Conclusion: Our outcomes demonstrated that the SVHCP was effective in reducing vocal fatigue and subjective vocal symptoms. The SVHCP can help improve voice-related quality of life and voice health for professional voice users. Further research is needed in conjunction with the IT field for the utilization of the SVHCP.
\end{abstract}

Keywords: Non-face-to-face voice therapy, Vocal fatigue management, Professional voice users
음성피로는 지속적인 음성사용 후 나타나는 음성과 관련된 부정 적인 변화를 의미하는 것으로 후두나 성대에 문제가 없는 조건에서 도 발생된다(McCabe \& Titze, 2002; Vilkman, 2004; Welham \& Maclagan, 2003). 또한, 음성평가에서 일반적으로 시행되는 음향학 적 검사, 공기역학적 평가, 전기성문파형 검사, 비디오후두내시경 등 에서 정상 성대와 구별되는 확실한 특징(hallmark)이 나타나지 않 는다. 이처럼, 음성피로의 시작과 존재를 구별할 수 있는 명확한 외 적 특징이 없기 때문에 음성에 대한 환자의 주관적 보고는 음성피 로의 중요한 평가 요소로 여겨진다(Buekers, 1998; Laukkanen, Ilomäki, Leppänen, \& Vilkman, 2008; Solomon, 2008). 음성피로로 인한 주관적인 증상에는 '음성 불편감과 음성 노력의 증가' '음도 범
위와 음성의 유연성 감소' ‘음성의 방사(projection)와 강도의 감소', ‘음질 저하', ‘음성을 사용한 날 증상 심화' '음성 휴식 후 증상의 개 선'등이 있으며, 본인 외에 이러한 증상을 구별하지 못할 수도 있다 (Gotaas \& Starr, 1993; Kim \& Choi, 2008a; Kitch \& Oates, 1994). 음 성피로는 음성사용 직후나 음성사용 사이 음성 휴식을 통해 증상 이 감소되고 음성이 회복될 수 있다는 특징으로 인해 임상현장과 음성장애 연구에 있어 간과되는 경향이 있다(Chang \& Karnell, 2004; Hunter \& Titze 2009; Solomon \& DiMattia, 2000; Welham \& Maclagan, 2003; Yiu \& Chan, 2003). 하지만, 회복되지 않는 음성피 로는 후두의 과기능과 이로 인한 성대조직의 병리학적 변화를 일으 키는 시작점이기 때문에 음성피로에 대한 이해는 음성장애의 평가 
와 치료에 있어 가장 근본적으로 고려되어야할 요소이다.

음성피로는 음성 오남용에서 비롯된 후두 내/외근과 목, 머리의 긴장과 자세 등 발성과 관련된 신체부위 근육의 과기능과 연관되어 발생되며, 근긴장성 발성장애나 성대점막의 병리학적 문제를 야기 할 수 있다(Welham \& Maclagan, 2003). 음성 오남용으로 인한 후 두외근의 피로는 후두의 수직적 위치를 상승시키는데, 후두 위치 의 상승은 성대점막의 강성(stiffness)을 증가시켜 발성 시 성대의 진동 충격을 증가시킨다. 또한, 후두내근의 피로 역시 성대 내전근 의 긴장을 증가시켜 발성 시 성대 진동의 진동 충격을 증가시킨다 (Solomon, 2008). 아울러, 음성을 유지하기 위한 환자의 음성 노력 이 증가하여 의식적으로 혹은 무의식적으로 명료한 음성을 유지하 기 위한 보상적인 발성이 형성되기도 한다. 이로 인해 정중위에서 조이는 듯한 내전형태가 나타나 성대 진동 시 진동 충격이 증가되 고 후두내근에 음성피로가 발생된다(Lucero, 1998; Verdolini \& Titze, 1995). 이와 같은 비효율적인 음성사용이 지속되면 성대의 미세구조가 진동 외상이나 진동 시 충격을 견딜 수 있는 한계를 넘 게 되어 성대 고유층의 조직이 변하고, 성대의 점탄성(viscosity)과 조직의 강성(tissue stiffness)이 증가되어 음질 변화가 나타날 뿐만 아니라 성대의 점막질환으로 이어진다(McCabe \& Titze, 2002; Solomon, 2008; Titze, 1984).

음성피로와 관련된 요소에는 직업적 음성사용, 성별, 음성위생, 음성 훈련 여부 등이 있다(Gelfer, Andrews, \& Schmidt, 1991; Song \& Pyo 2010). 특히, 직업적 음성사용자에게 음성피로는 직업 활동 의 제한 뿐만 아니라 사회적 의사소통에서의 어려움으로 이어질 수 있는 중요한 문제이다(Lee, Lim, Choi, \& Lim, 2019). 언어재활사 (Speech Language Pathologist)는 의뢰된 의사소통 장애 환자의 평 가와 치료, 상담 등의 직무수행에 있어 지속적인 음성사용이 요구 된다는 점에서 직업적 음성사용자로 분류할 수 있다(Koufman \& Isaacson, 1991). 최근 연구에 의하면 언어재활사의 $33.2 \%$ 는 만성적 인 음성문제를 가지고 있으며, $11.7 \%$ 는 음성문제로 인해 치료 수를 조절한 적이 있었다. 또한, $25.7 \%$ 는 치료 수를 줄이지 않았지만 직 업적 음성사용에 있어 음성 휴식의 필요성을 느낀다고 보고되었 다. 주된 호소는 쉰 목소리, 말할 때 힘이 들어감, 거친 음성, 말할 때 통증, 말할 때 힘이 듦, 노래에서 고음 발성 곤란 등이다. 언어재활사 의 경우 음성문제로 인한 치료 수의 감소가 직접적인 경제적 손실 로 이어질 수 있다는 점에서 음성문제가 개인의 삶에 미치는 영향 은 교사나 판매원, 상담원과 같은 다른 직업적 음성사용자에 비해 더 직접적일 수 있다(Kim \& Choi, 2018a, Kim \& Choi, 2018b).

음성위생법은 생활습관이나 음성사용의 조절, 습윤 관리와 생활 환경 개선에 대한 정보와 더불어 음성메커니즘에 대한 교육을 통해
직업적 음성사용자의 음성문제를 개선시키거나 음성건강을 유지 하는데 있어 효과적인 방법이다(Park, Sim, Chung, Park, \& Cho, 2004; Song \& Sim, 1999; Yoon \& Kim, 2013). 하지만, 이와같은 방법 은 간접적인 방법으로서 발성기관의 신체적 피로에서 비롯되는 음 성피로를 직접적으로 개선하는데 한계를 가진다. 또한, 음성피로감 을 호소하는 직업적 음성사용자는 음성 오남용뿐만 아니라 비효율 적인 방법으로 발성하는 경향이 있다(Choi \& Choi, 2013; Eustace, Stemple, \& Lee, 1996; Irving, Epstein, \& Harries, 1997). 따라서, 언 어재활사를 포함한 직업적 음성사용자의 음성피로 관리와 음성 건 강 유지를 위해 비효율적인 발성을 효율적인 발성으로 개선해주며, 음성과 관련된 신체적 불편감을 해소할 수 있는 방안이 필요하다.

반폐쇄성도운동(Semi Occluded Vocal Tract Exercise, SOVTE) 은 성도의 앞이나 뒤의 일부를 폐쇄하는 것으로, 폐쇄 시 나타나는 성문 내부의 압력과 기류의 증가를 이용한 음성치료 방법이다. 성 도의 앞인 입술이 반폐쇄 되면 흡기와 호기의 순환에 따라 산출되 어야 할 호기류가 충분히 산출되지 못해 구강의 압력이 증가하고 성대 쪽으로 다시 되돌아가는 역압(back pressure)이 형성되게 된 다. 이러한 역압은 성문상부의 압력을 높여 성문하부와의 압력 차 이를 감소시켜 음향관성을 증가시킨다. 이로 인해, 발성을 개시하고 유지하기 위한 최소발성역치압력(phonation threshold pressure, $\mathrm{PTP})$ 이 낮아져 적은 노력으로 발성을 할 수 있게 된다. 또한, 후두 의 수직적 위치가 낮아져 성대 점막의 강성이 저하되고, 성대가 약 간 외전된 형태에서 진동하기 때문에 성대의 진동 충격이 감소된다 (Guzman, Castro, Testart, Munoz, \& Gerhard, 2013; Kim, 2020; Radolf, Laukkanen, Horaček, \& Liu, 2014; Titze, 2006, 2018). 뿐만 아니라, SOVTE는 짧은 시간의 수행에도 즉각적인 음성개선의 효 과가 있어 음성치료 뿐만 아니라 음성평가의 진단 프로빙에도 효과 적으로 사용될 수 있다(Behrman, 2005, Kim, Lee, Choi, \& Choi, 2017).

후두마사지는 후두외근을 직접 마사지하는 것으로 후두의 과긴 장을 이완시키는데 가장 효과적인 방법이다(Aronson, 1990; Kim et al., 2017; Mathieson et al., 2009; Roy, Bless, Heisey, \& Ford, 1997). 이처럼, SOVTE와 후두마사지는 신체적 피로가 주요한 증상인 직 업적 음성사용자의 음성건강관리에 가장 적합한 방법으로서 유용 하게 사용될 수 있다. 이에 본 연구는 신체적 피로에서 비롯되는 직 업적 음성사용자의 음성피로 개선을 위해 SOVTE와 후두마사지를 적용한 자가음성건강관리 프로그램(Self-Voice Health Care Program, SVHCP)을 고안하였다. SVHCP는 발성 메커니즘, 음성 오남 용, 음성위생 등과 같은 음성에 관한 정보를 제공하고 조절하도록 하는 간접적인 음성치료 방법과 후두의 병리적인 문제를 개선시킬 
수 있는 직접적인 음성치료 방법이 결합된 것으로 직업적 음성사용 과 충분한 음성회복이 균형을 이루도록 함으로써 건강한 음성을 유지하고, 음성문제로 인한 직업 활동과 사회적 의사소통의 어려움 뿐만 아니라, 이로 인한 삶의 질의 저하를 예방하는 것을 목표로 한 다. SVHCP의 프로토콜은 치료의 시간과 장소의 제약을 극복하고 활용도 제고를 위해 수행 장면과 방법을 영상으로 제작하였으며, 이는 Covid-19시대에 요구되는 비대면 치료 형태이기도 하다.

따라서, 본 연구는 언어재활사를 대상으로 비대면 자가음성건강 관리 프로그램(SVHCP)의 수행에 따른 음성장애지수와 음성피로 도 검사, 주관적 음성증상의 비교를 통해 SVHCP가음성건강과 음 성피로 관리에 도움이 되는지 알아보고자 하였다. 또한 이를 통해, 직업적 음성사용자의 음성장애 예방뿐만 아니라 코로나 시대의 비 대면 음성치료에 도움되는 자료를 제공하고자 한다.

\section{연구방법}

\section{연구대상}

본 연구는 주 25 회기 이상 언어치료를 시행하며, 음성문제가 반 복적으로 지속되는 만성적 음성문제(chronic voice problem)가 있 다고 호소하는 언어재활사를 대상으로 실시하였다. 대상자는 호흡 기계, 내분비계, 소화기계 질환이나 감각장애가 없고, 알러지 치료 제나 호르몬제를 복용하지 않으며 또한, 이러한 문제로 의료기관 에서 진료를 받은 적이 없다고 보고하였다. 대상자는 언어재활사의 음성에 관한 온라인 설문에 성실히 응답한 언어재활사 26 명이다.

Table 1. Participants' information

\begin{tabular}{lr}
\hline Category & $\mathrm{N}(\%)$ \\
\hline Gender & \\
Male & $2(13)$ \\
Female & $13(87)$ \\
Age (yr) & \\
$20-29$ & $7(47)$ \\
$30-39$ & $6(40)$ \\
$40<$ & $2(13)$ \\
Session per week & \\
$26-35$ & $8(54)$ \\
$36-45$ & $5(33)$ \\
$46-55$ & $2(13)$ \\
Work place & \\
Hospital & $2(13)$ \\
Center & $8(54)$ \\
Welfare & $3(20)$ \\
Education office & $2(13)$ \\
\hline
\end{tabular}

대상자 모집은 네이버 언어재활사 커뮤니티의 연구 모집 글과 설문 에서 실험참여 의사를 밝힌 언어재활사를 대상으로 연구자가 보낸 실험참여 문자를 통해 모집되었으며, 실험참여에 대한 의사를 연 구동의로 간주하였다. 실험기간이 월경 주기와 중복된 대상자 3 명 은 연구대상에서 제외하였으며, 프로그램 기간 내 평소와 같은 직 업적 음성사용 외에 다른 특별한 음성 오남용이 있었다고 스스로 보고한 1 명 역시 제외하였다.

또한, 실험기간 동안 치료 세션이 주당 25회기 미만이었던 7명을 제외하고, 최종적으로 15 명(남 2 , 여 13 , 평균 연령 $31.19 \pm 5.18$ 세) 을 연구대상으로 하였다. 대상자의 근무기관은 병원, 복지관, 사설 언어치료센터와 교육청이었으며, 근무시간은 주 5 일이 12 명, 주 6 일 3명이었다. 주당 치료 회기는 26-35회기가 8명, 36-45회기 5명, 46-55 회기가 2 명이었고, 주당 평균치료 회기는 $34.4 \pm 9.4$ 회이었다(Table 1).

\section{실험설계}

자가음성건강관리 프로그램(SVHCP)

SVHCP는 직업적 음성사용자의 음성 행동 특성에 대한 선행연 구를 토대로 개발되었다(Kim \& Choi, 2018a, 2018b) 자가수행을 목표로 하는 SVHCP는 시간과 공간에 제약 받지 않고 스스로 수 행할 수 있도록 동영상으로 제작하였다(Figures 1, 2). 자가음성건

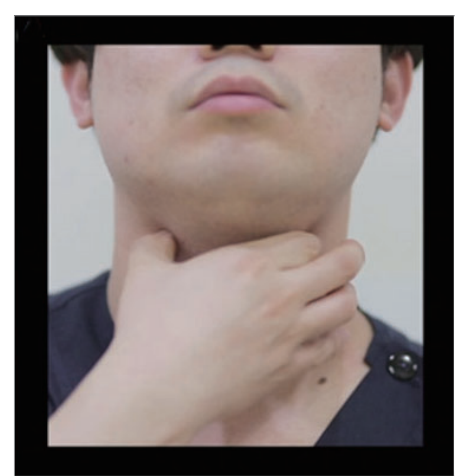

1. 후두마사지

[갑상연골 내리기]

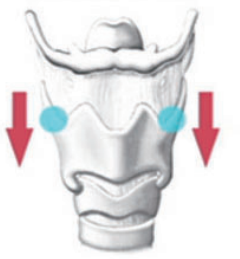

* 마사지는 호기 시에 하세응

(A)

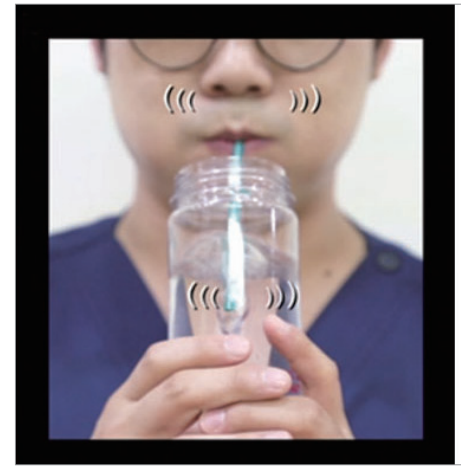

2. 빨대 발성

$\rightarrow$ 발성없이 거품내기

$\rightarrow$ 거품내며 발성하기

$\rightarrow$ 거품내며 발성 Pitch gliding <

$\rightarrow$ 거품내며 발성 Pitch gliding >

$\rightarrow$ 연장하기 High pitch

$\rightarrow$ 연장하기 Middle pitch

$\rightarrow$ 연장하기 Low pitch

$\rightarrow$ 거품내며 빨대 발성으로 노래하기

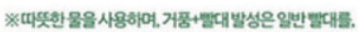

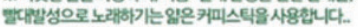

(B)

Figure 1. Still cut of self-voice health care program video: (A) laryngeal massage, (B) straw phonation with water. 


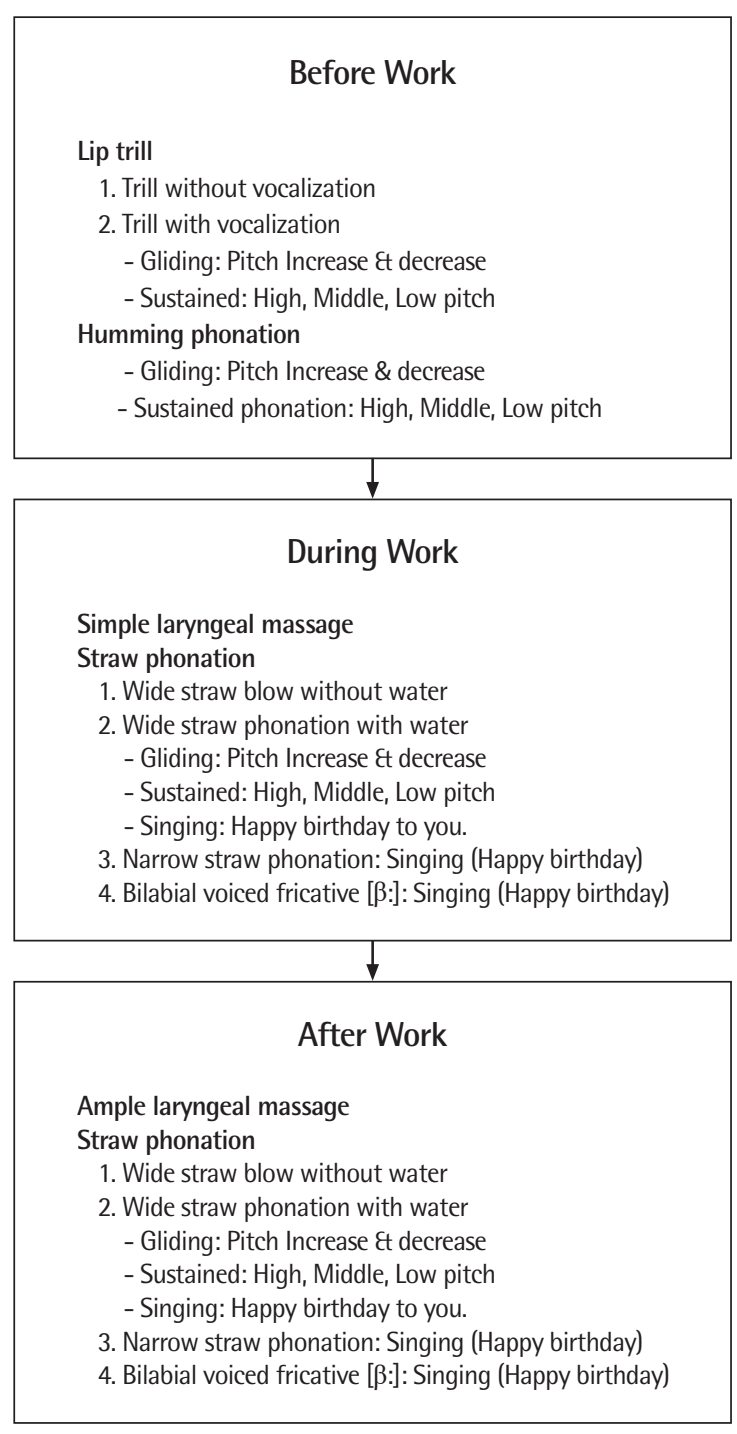

Figure 2. Protocol of self-voice health care program.

강관리 프로그램의 치료 전 단계는 입술트릴 발성과 허밍 발성을 수행한다. 먼저, 입술트릴 단계는 무성 입술트릴 이후 입술트릴 발 성을 글라이딩(gliding), 연장발성(sustained) 방법으로 실시하며, 이후 같은 방법으로 허밍 발성을 실시한다. 치료 중 단계에서는 갑 상설골근, 흉골설골근, 흥골갑상근, 견갑설골근, 윤상갑상근의 이 완을 목표로 하는 간단 후두마사지와 빨대발성을 실시한다. 빨대 발성 단계는 먼저 넓은 빨대로 빨대 불기 이후, 빨대발성을 글라이 딩, 연장발성, 노래(singing) 방법으로 실시한다. 이후 좁은 빨대로 노래 방법으로만 빨대발성을 실시한 후 유성양순마찰음(bilabial voiced fricative/(ß:/)을 노래 방법으로 실시한다. 치료 후 단계는 치 료 중 단계와 동일하나, 후두마사지에 있어 간단 후두마사지 영역 뿐만 아니라 이설골근, 경돌설골근, 악이복근, 악설골근의 이완을
목표로 한다. 프로그램의 빨대발성에 사용된 넓은 빨대의 사이즈 는 $0.5 \mathrm{~cm} \times 0.5 \mathrm{~cm} \times 17 \mathrm{~cm}$, 좁은 빨대의 사이즈는 $0.2 \mathrm{~cm} \times 0.5$ $\mathrm{cm} \times 17 \mathrm{~cm}$ 이며, 재질은 폴리프로필렌(polypropylene)이다. 연장발 성(Sustained Vocalization)의 음도 범위는 남자가 High: G3 (195 Hz), Middle: C3 $(130 \mathrm{~Hz})$, Low: G2 $(98 \mathrm{~Hz})$ 이며, 여자는 High: D4 $(293 \mathrm{~Hz})$, Middle: G3 $(195 \mathrm{~Hz})$, Low: C3 $(130 \mathrm{~Hz})$ 이었다. 연장과제 시 연장발성의 시간은 10 초로 제시하였으며, 유성양순마찰음(bilabial voiced fricative/ $\beta$ :/)과 허밍 발성 시 올바른 수행을 위해 안면 의 진동감을 충분히 느끼며 수행하도록 권고하였다.

\section{실험절차}

본 연구의 실험 대상자들은 동영상(5분)을 통해 자가음성건강관 리 프로그램을 숙지하였으며, 1 주일간 자가음성건강관리 프로그 램을 스스로 수행하였다. 실험 참가자들에게 매일 치료 전과 모든 치료 후 각 1 회, 치료 중은 3 회 이상 수행을 하도록 제시하였으며, 실제 대상자들이 실시한 프로그램 평균 수행도는 치료 전 100\% (1.0회), 치료 중 $46 \%$ (1.4회), 치료 후 $100 \%$ (1.0회)였다. 또한, 연구 참여자는 제공된 기록표에 매일 자가음성건강관리 프로그램의 수 행여부와당일의 치료 회기를 기록하였다.

\section{음성측정}

음성은 Google 설문지 양식을 이용해 실험 전과 후 대상자들의 자기보고에 의해 측정되었다. 환자의 주관적 보고가 음성피로의 평가에 중요한 요소임(Buekers, 1998; Laukkanen et al., 2008; Solomon, 2008)을 고려하여, 언어재활사의 음성과 음성피로가 가장 잘 반영되는 환자 중심의 주관적 음성평가인 (1) 한국판 음성장애 지수-10 (Korea Voice handicap Index-10, K-VHI-10; Yun, Kim, Son, \& Choi, 2008)과, (2) 한국판 음성피로도 검사(Korean version of Vocal Fatigue Index, K-VFI; Cho, 2016)를 사용하여 대상 자의 음성을 측정하였다. 또한, (3) 주관적인 음성 증상의 유무는 총 14 항목으로 없음 $=0$ 점, 가끔 $=1$ 점, 자주 $=2$ 점, 항상 $=3$ 점으로 평가하였다. 항목은 '말할 때 목에 힘이 들어감', '말할 때 목소리가 끊어짐', '말할 때 힘이 듦', '말할 때 목에 통증', '말할 때 목소리가 갈라짐', ‘음성피로감 경험, ‘음도 저하, '음도 상승, '노래에서 고음 발성 곤란' '노래에서 저음발성 곤란', '바람 새는 소리', '쥐어짜는 소리', ‘약한 목소리', '쉰 목소리'이다(Kim \& Choi, 2018a, 2018b). 음성장애지수(Voice Handicap Index, VHI)는 총 30문항으로 구 성되어 음성장애가 일상생활에 미치는 정도를 신체적, 기능적 및 감정적 측면에서 환자가 직접 평가하는 주관적인 음성장애 검사로 각 문항을 5 점 척도로 평가한다. 본 연구에서는 시간 경제성 및 효 
용성을 위해 VHI-10의 한국판 버전인 K-VHI-10 (Yun et al., 2008) 을 사용하였다. 음성피로지수 검사(Vocal Fatigue Index, VFI)는 환 자 자신이 음성피로에 대해 느끼는 정도를 평가하는 주관적인 검 사이다. 음성회피 및 피로, 음성사용 시 신체적 불편, 휴식 후 음성 향상에 관련된 3 가지 영역으로 총 19문항으로 구분되어 있다. 평 가는 0-4점 체계로 점수가 높을수록 음성으로 인한 주관적으로 느끼는 음성피로지수가 높다고 평가한다(Nanjundeswaran, Jacobson, Gartner-Schmidt, \& Abbott, 2015). 휴식 후 음성향상에 관한 3 문항은 다른 문항과 달리 긍정형 문장으로 구성되어 역채점 하여 결 과를 분석하였으며, 한국판 버전인 K-VFI $(\mathrm{Cho}, 2016)$ 를 사용하였다.

\section{결과처리}

수집한 자료를 통해 자가음성건강관리 프로그램 수행 전과 후의 음성차이를 알아보기 위해 SPSS (Statistics Package for the Social Science version 21.0)를 이용하여 비모수 검정인 Wilcoxon's signedranks test를 실시하였으며, $95 \%$ 수준에서 유의성을 검증하였다.

Table 2. Comparisons of subjective voice measures before and after self-voice health care program

\begin{tabular}{lcccc}
\hline & Before & After & $Z$ & $p$ \\
\hline K-VHI-10 & $9.07(8.10)$ & $5.4(5.57)$ & -2.380 & $.017^{*}$ \\
K-VFI-fatigue & $24.93(8.14)$ & $13.4(9.86)$ & -2.857 & $.004^{* *}$ \\
K-VFI-physical & $10.20(3.41)$ & $5.6(5.34)$ & -2.344 & $.019^{*}$ \\
K-VFI-rest & $4.60(3.56)$ & $2.73(2.96)$ & -2.965 & $.003^{* *}$ \\
K-VFI-total & $39.73(10.18)$ & $21.73(13.06)$ & -2.786 & $.005^{* *}$ \\
\hline
\end{tabular}

$\mathrm{K}-\mathrm{VHI}-10=$ Korean version of Voice Handicap Index-10; K-VFI=Korean version of Vocal Fatigue Index.

${ }^{*} p<.05,{ }^{* *} p<.01$.

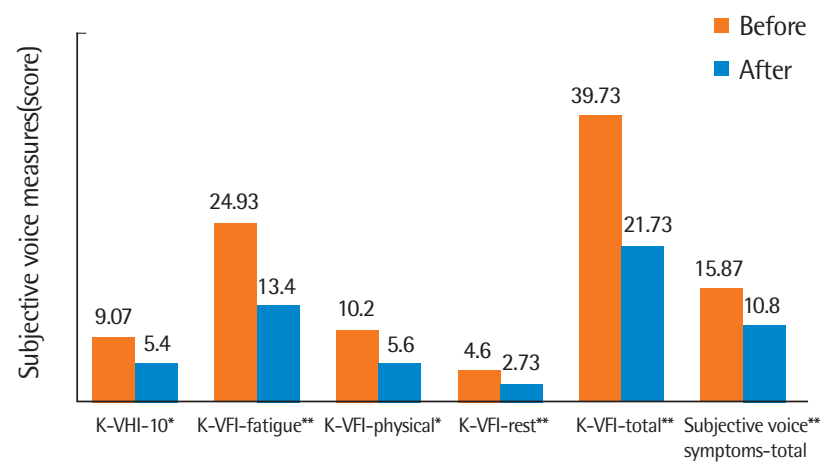

Figure 3. Comparisons of subjective voice measures before and after selfvoice health care program.

$\mathrm{K}-\mathrm{VHI}-10=$ Korean version of Voice Handicap Index-10; K-VFI= Korean version of Vocal Fatigue Index.

${ }^{*} p<.05,{ }^{* *} p<.01$.

\section{연구결과}

\section{음성장애지수와 음성피로도 검사}

SVHCP의 효과를 알아보기 위해 실험 전, 후에 실시한 K-VHI-10 과 $\mathrm{K}-\mathrm{VFI}$ 의 점수 차이를 비교하였다. 그 결과, $\mathrm{K}-\mathrm{VHI}-10(p=.017)$ 와 K-VFI-fatigue ( $p=.004), \mathrm{K}-\mathrm{VFI}-$ physical $(p=.019)$, K-VFI-rest ( $p=.003), \mathrm{K}-\mathrm{VFI}$-total $(p=.005)$ 가 유의하게 감소한 것으로 나타났 다(Table 2, Figure 3).

\section{주관적인 음성증상}

$\mathrm{SVHCP}$ 의 효과를 알아보기 위해 실험 전, 후에 실시한 주관적인 음성증상의 점수 차이를 비교하였다. 그 결과, 주관적인 음성증상 14 개 중 '말할 때 목에 힘이 들어감 $(p=.007)$, 말할 때 목소리가 갈 라짐 $(p=.007)$, 말할 때 통증 $(p=.034)$, 노래 시 고음곤란 $(p=.017)$,

Table 3. Comparisons of subjective voice symptoms measures before and after self-voice health care program

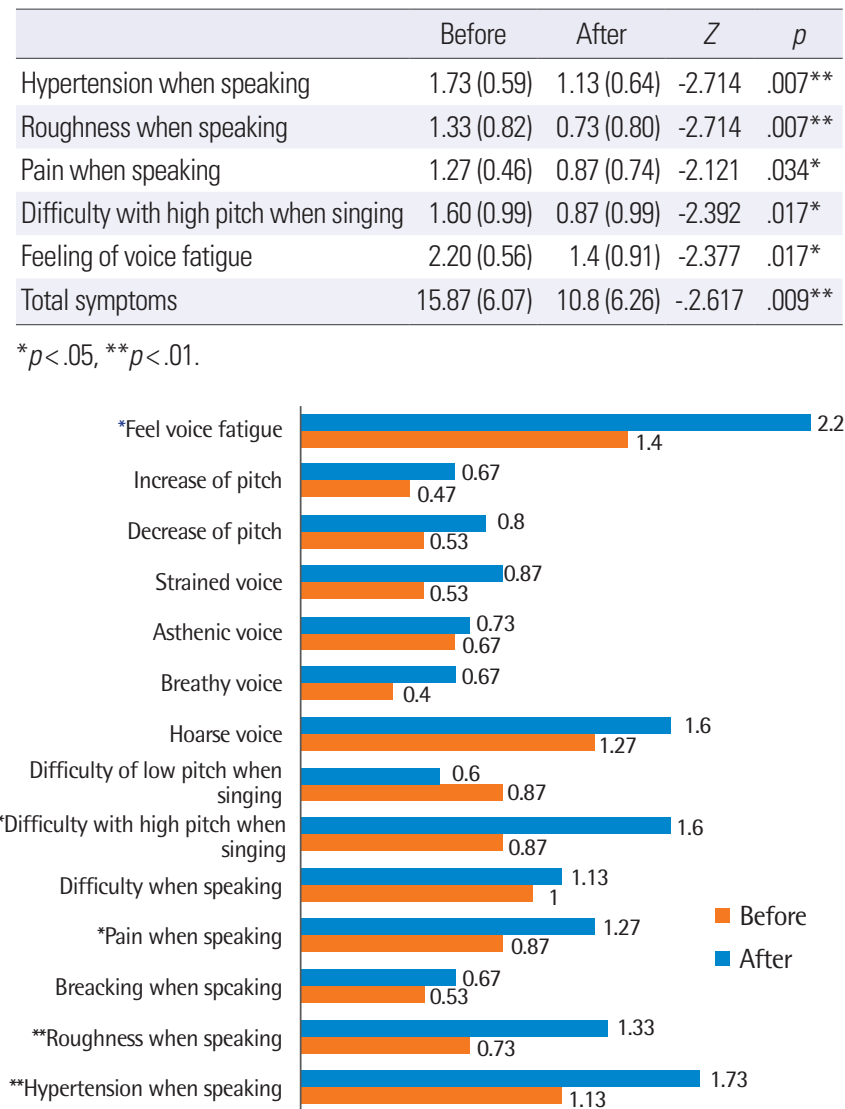

Figure 4. Comparison of subjective voice symptoms measures(4- point Likert scale) before and after self-voice health care program; $0=$ no symptom, $1=$ sometimes, $2=$ Frequent, $3=$ Always.

${ }^{*} p<.05,{ }^{* *} p<.01$. 
음성피로감 경험 $(p=.017)^{\prime}$ 이 유의한 감소를 나타내었으며, 음성증 상의 총점 $(p=.009)$ 도 유의하게 감소된 것으로 나타났다(Table 3, Figures 3,4$)$.

\section{논의 및 결론}

본 연구는 반폐쇄성도운동과 후두마시지를 적용하여 고안한 자 가음성건강관리 프로그램의 효과를 알아보기 위한 것이다. 이를 위해 직업적 음성사용자인 언어재활사가 1 주일간 수행하였으며, 실 험 전과 후의 음성을 비교하였다. 그 결과, 프로그램 수행에 따른 KVHI-10과 K-VFI의 총점과 하위 항목 모두 유의한 감소가 나타났 다. 특히, 음성사용 시 신체적 불편을 나타내는 K-VFI-physical과 휴식으로 인한 음성향상을 나타내는 K-VFI-rest의 변화는 SVHCP 가 직업적 음성사용에 의해 비롯되는 발성기관의 신체적 피로의 개 선에 효과적인 방법임을 시사한다. Kim과 Choi (2018a)에서 '말할 때 힘이 들어감', '말할 때 목에 통증, '노래 시 고음발성 곤란, '음성 피로감 경험'은 언어재활사의 주된 음성증상이었다. 본 연구에서 주관적인 음성증상의 총점뿐만 아니라 주관적인 음성증상 14 개 중 ‘말할 때 힘이 들어감', ‘말할 때 목소리가 갈라짐' '말할 때 목에 통증', ‘노래 시 고음발성 곤란, ‘음성피로감 경험’이 실험 전에 비해 각각 유의하게 감소한 것으로 나타났으며, 이와같은 결과는 SVHCP 가 직업적 음성사용에서 비롯되는 언어재활사의 음성피로를 개선 시키고, 음성건강관리에 효과적인 방법이 될 수 있음을 시사한다.

SVHCP에 적용된 SOVTE는 성도에서 진동하는 진동원에 따라 단일 진동원(single source vibration)과 이중 진동원(double source vibration)으로 구분할 수 있다. 단일 진동원은 손으로 입 가리고 발 성하기, 허밍, 빨대발성, 이중 진동원은 입술트릴 발성, 혀트릴 발성, 물저항 빨대발성 등이 있다. Andrade 등(2014)은 단일 진동원의 SOVTE 시 기본주파수와 성문폐쇄비율의 변화가 없고, 기본 주파 수와 제 1 포먼트의 차이가 크지 않아 성도는 자가운동을 촉진하는 관성리액턴스(inertive reactance)가 증가되어 성대의 진동이 쉽게 유지된다고 보고하였다. 반면, 이중 진동원은 기본주파수와 성문 폐쇄비율이 변화되고 기본주파수와 제 1 포먼트의 차이가 단일 진 동원에 비해 크기 때문에 단일 진동원 보다 관성리액턴스가 낮아 발성을 쉽게 만드는 효과가 적지만, 성문사이 압력의 변화로 인해 성도와 성대에서의 마사지 효과가 나타난다고 보고하였다. 본 연구 에서는 SOVTE는 치료 전에 발성기관을 이완시키는 vocal warming-up의 효과를 주었으며, 치료 중과 치료 후에는 직업적 음성사 용으로 인한 후두근육의 피로를 해소하고, 성대의 진동 충격을 감 소시켜 줌으로써 음성 외상을 예방하는 효과가 있었다. 또한, 물거
품이 발생하여 즉각적으로 시각적인 피드백을 제공할 수 있었다. 후두마사지는 후두외근의 과긴장을 개선하는데 한계가 있는 SOVTE를 보완하였다. 결론적으로, 본 연구의 SVHCP를 통해 언어재 활사의 음성피로 개선을 확인할 수 있었다.

본 연구에서는 SVHCP의 활용을 위해 프로토콜에 따른 수행방 법과 수행영상을 5 분 분량의 동영상으로 제작하였다. 실험 후 참여 한 대상자들에게 동영상의 내용 이해 정도에 대해 물었을 때 '쉬웠 음(8명)', ‘보통이었음(7명), '어려웠음(0명)'이라고 응답하였고 동영 상의 길이에 대해서는 '짧았음(2명)' '길었음(1명), '적당했음(12명)' 이라고 응답하였다. SVHCP 수행의 어려운 점에 대한 질문에서는 '후두마사지가 어려웠다', '빨대발성이 어려웠다', '내원 환자가 볼까 부끄러웠다', '올바른 수행에 대한 피드백이 없어 아쉬웠다', '치료 중 시간을 마련하기 어려웠다'라고 응답하였다. 이를 통해 동영상 을 통한 간접교육이 장소와 시간의 제약을 받지 않고 활용될 수 있 음을 확인 할 수 있었던 반면, 직접적인 대면교육이 없기 때문에 SVHCP의 수행의 질적인 측면에서는 한계가 있을 수 있음이 나타 났다. 또한, 유익했던 점에 대해서는 '목에 힘이 덜 들어가서 좋았 다', '목 통증이 줄었다', ‘음성피로가 감소한 것을 느꼈다' '후두마사 지가 가장 효과적이었다, ‘음성문제에 대한 자각을 할 수 있어 좋았 다, ‘빨대 발성이 효과적이었다’라고 응답하며, SVHCP가 직업적 음성사용으로 인한 발성기관의 신체적인 문제를 개선하는데 효과 적임을 확인할 수 있었다. 기타 의견으로는 '세미나가 열린다면 참 석해서 배워 보고 싶다', '실험 종료 후에도 지속적으로 할 생각이 있다, '이러한 연구들을 통해 언어재활사의 근무환경과 여건이 개 선되는 방향으로 이어지길 바란다' 등이 있었다.

Kwon과 Kwon (2007)은 성대결절 환자 15명을 대상으로 복식호 흡 훈련 프로그램과 Self Voice Feedback 프로그램을 이용한 자가 음성치료를 실시하였다. 그 결과, 치료 후 음향학적 변수와 청지각 적 평가 결과의 유의한 감소를 보고하였다. Van leer와 Connor (2012)는 자가음성훈련법을 비디오 플레이어로 제공한 그룹과 서 면으로 제공한 그룹의 수행과 치료 동기를 비교하였다. 그 결과 비 디오 플레이어 그룹이 자가훈련의 수행 횟수가 더 높게 나타났으며, 치료에 대한 동기 역시 더 높았다. 치료 전후음성을 측정하여 비교 하지 않았으나, 적극적인 자가훈련과 치료에 대한 동기 증가는 성공 적인 음성치료의 중요한 요인임을 고려할 때, 음성치료 시 동영상을 활용하는 것이 음성치료에 효과적인 방법이 될 수 있음을 시사하 였다. Tindall, Huebner, Stemple과 Kleinert (2008)는 파킨슨병 환 자 24명을 대상으로 비디오폰을 사용하여 LSVT 자가훈련을 실시 하였다. 그 결과, 모음 발성, 읽기 문단, 독백 등에서 음성의 강도 증 가를 보고하였다. 이와 같은 선행연구는 자가음 성건강관리를 위해 
동영상을 매개로 사용한 본 연구와 일치하는 결과이다.

교사의 음성문제는 학생들의 학업 성취와 같은 교육의 질 저하 로 이어질 수 있다(Rogerson \& Dodd, 2005). 이와 마찬가지로, 언 어재활사 음성문제 역시 치료 서비스의 질에 부정적인 영향을 미 칠 수 있을 것이다. Van Houtte, Claeys, Wuyts와 Van Lierde (2011) 그리고 Richter, Nusseck, Spahn과 Echternach (2016)는 교사의 음 성건강을 위해 교사 교육과정 중에서 음성위생과 관리에 대한 교 육의 필요성을 제시하였다. 언어재활사 역시 직업적 음성사용자로 써 언어재활사가 경험할 수 있는 음성문제와 효율적인 음성관리 방안에 대한 교육이 제공될 필요가 있겠다.

본 연구는 예비연구로 대상자 수가 작고 성별을 고려하지 못하였 으며, 주당 치료 회기는 통제하였으나 회기 시간에 대한 통제는 이 루어지지 못했다. 추후 연구에서는 이를 보완할 필요가 있겠으며, 다양한 직업적 음성사용자와 전문 음성사용자를 대상으로 연구 를 확대할 필요가 있겠다. 또한, 프로그램 수행횟수와 기간에 따른 효과와 이후 효과 유지에 대한 연구가 후속되어야 하겠다. 본 연구 에서 동영상을 통해 자가음성건강관리 프로그램을 제시하였는데, 추후에는 ZOOM과 같은 앱을 통해 실시간 온라인 치료에 대한 시 도와 자가음성건강관리 프로그램의 활용성을 위해 스마트폰 앱이 나 게임 형태로 구현하는 IT분야와의 융합연구가 필요하겠다.

\section{REFERENCES}

Andrade, P. A., Wood, G., Ratcliffe, P., Epstein, R., Pijper, A., \& Svec, J. G. (2014). Electroglottographic study of seven semi-occluded exercises: lax vox, straw, lip-trill, tongue-trill, humming, hand-over-mouth, and tonguetrill combined with hand-over-mouth. Journal of Voice, 28(5), 589-595.

Aronson, A. E. (1990). Clinical voice disorders: an interdisciplinary approach. New York, NY: Thieme.

Behrman, A. (2005). Common practices of voice therapists in the evaluation of patients. Journal of Voice, 19(3), 454-469.

Buekers, R. (1998). Are voice endurance tests able to assess vocal fatigue?. Clinical Otolaryngology \& Allied Sciences, 23(6), 533-538.

Chang, A., \& Karnell, M. (2004). Perceived phonatory effort and phonation threshold pressure across a prolonged voice loading task: a study of vocal fatigue. Journal of Voice, 18(4), 454-466.

Cho, J. K. (2016). Acoustic characteristics and vocal fatigue associated with professional voice use of female telemarketers (Master's thesis). Daegu Catholic University, Gyeongsan, Korea

Choi, S. H., \& Choi, C. H. (2013). The characteristics of voice handicap index and vocal misuse and 295 overuse in female elementary teachers. Phonetics and Speech Sciences, 5(4), 53-61.

Eustace, C. S., Stemple, J. C., \& Lee, L. (1996). Objective measures of voice production in patients complaining of laryngeal fatigue. Journal of Voice, 10(2), 146-154.

Gelfer, M. P., Andrews, M. L., \& Schmidt, C. P. (1991). Effects of prolonged loud reading on selected measures of vocal function in trained and untrained singers. Journal of Voice, 5(2), 158-167.

Gotaas, C., \& Starr, C. D. (1993). Vocal fatigue among teachers. Folia Phoniatrica, 45(3), 120-129.

Guzman, M., Castro, C., Testart, A., Munoz, D., \& Gerhard, J. (2013). Laryngeal and pharyngeal activity during semioccluded vocal tract postures in subjects diagnosed with hyperfunctional dysphonia. Journal of Voice, 27(6), 709-716.

Hunter, E. J., \& Titze, I. R. (2009). Quantifying vocal fatigue recovery: dynamic vocal recovery trajectories after a vocal loading exercise. Annals of Otology, Rhinology \& Laryngology, 118(6), 449-460.

Irving, R. M., Epstein, R., \& Harries, M. L. L. (1997). Care of the professional voice. Clinical Otolaryngology \& Allied Sciences, 22(3), 202-205.

Kim, J. S. (2020). Vocal fold vibration characteristics of the semi-occluded vocal tract exercise using vibration simulator (Doctoral dissertation). Daegu Catholic University, Gyeongsan, Korea.

Kim, J. S., \& Choi, S. H. (2018a). Voice problems and self-care practice for vocal health: current status of Korean speech-language pathologists. Communication Sciences \& Disorders, 23(2), 414-424.

Kim, J. S., \& Choi, S. H. (2018b). Vocal fatigue and voice-related quality of life in Korean speech-language pathologists. Communication Sciences \& Disorders, 23(4), 1078-1090.

Kim, J. S., Lee, D. W., Choi, C. H., \& Choi, S. H. (2017). Effects of laryngeal massage and semi-occluded vocal tract exercises for patients with hyperfunctional dysphonia. Communication Sciences \& Disorders, 22(4), 806817.

Kitch, J. A., \& Oates, J. (1994). The perceptual features of vocal fatigue as selfreported by a group of actors and singers. Journal of Voice, 8(3), 207-214.

Koufman, J. A., \& Isaacson, G. (1991). The spectrum of vocal dysfunction. Otolaryngologic Clinics of North America, 24(5), 985-988.

Kwon, S. B., \& Kwon, S. W. (2007). The effect of self voice feedback training using praat on the voice improvement of patient with vocal nodules. Journal of Special Education \& Rehabilitation Science, 46(1), 191-215.

Laukkanen, A. M., Ilomäki, I., Leppänen, K., \& Vilkman, E. (2008). Acoustic 
measures and self-reports of vocal fatigue by female teachers. Journal of Voice, 22(3), 283-289.

Lee, S. J., Lim, S. E., Choi, H. S., \& Lim, J. Y. (2019). A comparison of voice activity and participation profiles according to the patterns of professional voice use. Communication Sciences \& Disorders, 24(3), 758-769.

Lucero, J. C. (1998). Optimal glottal configuration for ease of phonation. Journal of Voice, 12(2), 151-158.

McCabe, D. J., \& Titze, I. R. (2002). Chant therapy for treating vocal fatigue among public school teachers. American Journal of Speech-Language Pathology, 11(4), 356-369.

Mathieson, L., Hirani, S. P., Epstein, R., Baken, R. J., Wood, G., \& Rubin, J. S. (2009). Laryngeal manual therapy: a preliminary study to examine its treatment effects in the management of muscle tension dysphonia. Journal of Voice, 23(3), 353-366.

Nanjundeswaran, C., Jacobson, B. H., Gartner-Schmidt, J., \& Abbott, K. V. (2015). Vocal Fatigue Index (VFI): development and validation. Journal of Voice, 29(4), 433-440.

Park, S. S., Sim, H. S., Chung, S. M., Park, Y. H., \& Cho, S. H. (2004). The effect of vocal hygiene for the female elementary school teachers. Journal of the Korean Society of Laryngology, Phoniatrics and Logopedics, 15(1), 27-30.

Radolf, V., Laukkanen, A. M., Horačk, J., \& Liu, D. (2014). Air-pressure, vocal fold vibration and acoustic characteristics of phonation during vocal exercising. Part 1: Measurement in vivo. Engineering Mechanics, 21(1), 5359.

Richter, B., Nusseck, M., Spahn, C., \& Echternach, M. (2016). Effectiveness of a voice training program for student teachers on vocal health. Journal of Voice, 30(4), 452-459.

Rogerson, J., \& Dodd, B. (2005). Is there an effect of dysphonic teachers' voices on children's processing of spoken language?. Journal of Voice, 19(1), 4760.

Roy, N., Bless, D. M., Heisey, D., \& Ford, C. N. (1997). Manual circumlaryngeal therapy for functional dysphonia: an evaluation of short-and longterm treatment outcomes. Journal of Voice, 11(3), 321-331.

Solomon, N. P. (2008). Vocal fatigue and its relation to vocal hyperfunction. International Journal of Speech-Language Pathology, 10(4), 254-266.

Solomon, N. P., \& DiMattia, M. S. (2000). Effects of a vocally fatiguing task and systemic hydration on phonation threshold pressure. Journal of Voice, 14(3), 341-362.

Song, Y. K., \& Pyo, H. Y. (2010). A preliminary study on voice symptoms and Korean Voice Handicap Index of speech language pathologists. Phonetics and Speech Sciences, 2(2), 123-133.

Song, Y. K., \& Sim, H. S. (1999). Treatment efficacy of group vocal hygiene education for middle school teachers: acoustical analysis of voice and selfevaluation of vocal fatigue before and after the education. Korean Journal of Communication \& Disorders, 4(1), 1-22.

Titze, I. R. (2006). Theoretical analysis of maximum flow declination rate versus maximum area declination rate in phonation. Journal of Speech, Language, and Hearing Research. 49(2), 439-447.

Titze, I. R. (2018). Major benefits of semi-occluded vocal tract exercises. Journal of Singing, 74(3), 311-312.

Titze, I. R. (1984). Vocal fatigue: some biomechanical considerations. In V. L. Lawrence (Ed.), Transcripts of the twelfth symposium: care of the professional voice. Part I: Scientific papers (pp. 97-104). New York: The Julliard School.

Tindall, L. R., Huebner, R. A., Stemple, J. C., \& Kleinert, H. L. (2008). Videophone-delivered voice therapy: a comparative analysis of outcomes to traditional delivery for adults with Parkinson's disease. Telemedicine and eHealth, 14(10), 1070-1077.

Verdolini, K., \& Titze, I. R. (1995). The application of laboratory formulas to clinical voice management. American Journal of Speech-Language Patholo$g y, 4(2), 62-69$.

Van Houtte, E., Claeys, S., Wuyts, F., \& Van Lierde, K. (2011). The impact of voice disorders among teachers: vocal complaints, treatment-seeking behavior, knowledge of vocal care, and voice-related absenteeism. Journal of Voice, 25(5), 570-575.

Van Leer, E., \& Connor, N. P. (2012). Use of portable digital media players increases patient motivation and practice in voice therapy. Journal of Voice, 26(4), 447-453.

Vilkman, E. (2004). Occupational safety and health aspects of voice and speech professions. Folia Phoniatrica et Logopaedica, 56(4), 220-253.

Welham, N. V., \& Maclagan, M. A. (2003). Vocal fatigue: current knowledge and future directions. Journal of Voice, 17(1), 21-30.

Yiu, E. M., \& Chan, R. M. (2003). Effect of hydration and vocal rest on the vocal fatigue in amateur karaoke singers. Journal of Voice, 17(2), 216-227.

Yun, Y. S., Kim, H. H., Son, Y. I., \& Choi, H. S. (2008). Validation of the Korean Voice Handicap Index (K-VHI) and the clinical usefulness of Korean VHI-10. Korean Journal of Communication Disorders, 13(2), 216-241.

Yoon, J. H., \& Kim, S. W. (2013). A survey on participants satisfaction of vocal hygiene education: a preliminary study. Phonetics and Speech Sciences, 5(3), 83-93. 


\section{국문초록}

\section{자가음성건강관리 프로그램을 이용한 비대면 음성치료의 효과}

\section{김지성 $\cdot$ 최성희 ${ }^{2}$}

1충북대학교병원 이비인후과, ${ }^{2}$ 대구가톨릭대학교 언어청각치료학과

배경 및 목적: Covid-19로 인해 비대면 치료의 필요성이 많이 대두되고 있다. 직업적 음성사용자는 지속적인 음성사용으로 인해 음성 질환의 위험성이 높다. 본 연구는 한국 언어재활사의 음성특성을 토대로 직업적 음성사용자의 음성피로 개선을 위해 고안된 맞춤형 '자 가음성건강관리 프로그램(Self-Voice Health Care Program)'의 효과를 알아보는 것이다. 방법: 대상자는 주당 25회기 이상 치료하고 있 으며, 음성문제를 호소하는 언어재활사 15명(남 2명, 여 13명, 평균연령 31.19세)이다. 대상자는 실험모집 문자와 언어재활사 커뮤니티의 게시글을 통해 모집되었다. 자가음성건강관리 프로그램은 5 분 분량의 동영상으로 제공되었으며, 대상자들은 1 주일간 자가음성건강관 리 프로그램을 수행하였다. 음성측정은 실험 전과 후에 실시되었다. 결과: SVHCP 수행 후 K-VHI-10 ( $p=.017)$, 세부영역 K-VFI-fatigue ( $p=.004)$, K-VFI-physical ( $p=.019)$, K-VFI-rest $(p=.003)$, K-VFI-total $(p=.005)$ 과 주관적 음성증상 $(p=.009)$ 이 유의하게 감소한 것으 로 나타났다. 또한, 주관적 음성증상 중 말할 때 목에 힘이 들어감 $(p=.007)$, 말할 때 목소리가 갈라짐 $(p=.007)$, 말할 때 통증 $(p=.034)$, 노래 시 고음곤란 $(p=.017)$, 음성피로감 경험 $(p=.017)$ 항목이 유의하게 감소하였다. 논의 및 결론: 자가음성건강관리 프로그램은 직업 적 음성사용에서 비롯되는 언어재활사의 음성피로 개선에 효과적이었으며, 직업적 음성사용자의 음성건강관리에 도움이 될 수 있는 방안이며, 활용도 제고를 위해 스마트 폰 앱 구현과 같은 IT분야와의 융합연구가 필요하다.

핵심어: 비대면 음성치료, 음성피로 관리, 직업적 음성사용자

\section{참고문헌}

김지성 (2020). 진동 시뮬레이터를 이용한 반폐쇄성도운동의 성대진동 특성 연구. 대구가톨릭대학교 대학원 박사학위논문. 김지성, 최성희 (2018a). 한국 언어재활사들의 음 성문제와음성건강을 위한 자가관리 현황. Communication Sciences \& Disorders, 23(2), 414-424. 김지성, 최성희 (2018b). 한국 언어재활사의 음성피로 및 음성과 관련된 삶의 질. Communication Sciences \& Disorders, 23(4), 1078-1090.

김지성, 이동욱, 최철희, 최성희 (2017). 후두마사지와 반폐쇄성도훈련이 과기능적 음성장애 환자의 음성개선에 미치는 효과. Communication Sciences \& Disorders, 22(4), 806-817.

권순복, 권순우 (2007). Praat을 이용한 자가 음성훈련 프로그램이 성대결절 환자의 음성개선에 미치는 효과. 특수교육재활과학연구, 46(1), $191-215$. 박성신, 심현섭, 정성민, 박영학, 조승호 (2004). 초등학교 여교사를 대상으로 한 음성위생법 효과성. 대한음성언어의학회지, 15(1), 27-30.

송윤경, 심현섭 (1999). 음성위생법 그룹교육의 유효성에 관한 연구: 중등교사의 음성 위생법 교육 전 후의 음성분석 및 음성피로 자가평가를 통하여. 언어청각장애연구, 4(1), 1-22.

송윤경, 표화영 (2010). 언어치료사의 음성증상 및 한국어판 음성장애지수에 대한 예비연구. 말소리와음성과학, 2(2), 123-133.

윤지혜, 김선우 (2013). 음성위생교육 만족도에 대한 예비연구. 말소리와음성과학, 5(3), $83-93$.

이승진, 임성은, 최홍식, 임재열 (2019). 직업적 음성사용 패턴에 따른 음성 활동 및 참여 프로파일 비교. Communication Sciences \& Disorders, 24(3), 758-769.

\section{ORCID}

김지성(제1저자, 언어재활사 https://orcid.org/0000-0003-2363-5060); 최성희(교신저자, 교수 https://orcid.org/0000-0003-2365-6187) 